Yuzuncu Yil University
Journal of Agricultural Sciences

Research Article

\title{
Some Biochemical Parameters of Black and White Myrtle communis L. Fruits Subjected to Different Preservation Methods
}

\author{
Büşra BAKAR ${ }^{1}$, Meltem ÇAKMAK ${ }^{2}$, Dursun ÖZER ${ }^{3}$, Fikret KARATAS ${ }^{* 4}$, Sinan SAYDAM ${ }^{5}$ \\ ${ }^{1,2,3}$ Department of Chemical Engineering, Faculty of Engineering, Firat University, 23119 Elazig, Turkey \\ ${ }^{4,5}$ Faculty of Science, Department of Chemistry, Firat University, Elazig, Turkey \\ ${ }^{1} \mathrm{https} / / /$ orcid.org/0000-0001-7793-1119 ${ }^{2} \mathrm{https} / / /$ orcid.org/0000-0002-6291-863X ${ }^{3} \mathrm{https}: / /$ orcid.org/0000-0002-7225-8903 \\ ${ }^{4}$ https://orcid.org/0000-0002-0884-027X ${ }^{5}$ https://orcid.org/0000-0003-1531-5454 \\ *Corresponding author e-mail: fkaratas@firat.edu.tr
}

\section{Article Info}

Received: 25.02.2021

Accepted: 18.06.2021

Online Published:15.09.2021

DOI: $10.29133 /$ yyutbd.886684

\section{Keywords}

Amino acids,

Antioxidant capacity,

Myrtle,

Phenolic substance,

Preservation,

Vitamins.

\begin{abstract}
In this work, black and white Myrtus communis L. (myrtle) fruits some biochemical parameters were investigated such as vitamins, carotenes, functional peptides, oxidative stress markers (OSM), total phenolic (TP) and flavonoid (TF) substances, antioxidant capacity (AC) and amino acids contents. The black myrtle fruits had generally higher amounts of vitamins, TP, AC and amino acid (AA) contents than the white myrtle fruits. The biochemical contents of myrtle fruits dried in the sun light and microwave (MW) were found to be lower than the frozen fruits $(\mathrm{P}<0.05)$. A significant increase was observed in the amount of oxidised glutathione (GSSG) and malondialdehyde (MDA) in myrtle fruits as a result of drying $(\mathrm{P}<0.05)$. Amounts of total AA in the black and white myrtle fruits were found to be 31.37 and $21.89 \mathrm{mg} \mathrm{g}^{-1} \mathrm{DW}$, respectively. From the results obtained, it can be said that black myrtle fruit is a better nutrition source than white myrtle fruits and freezing is the most appropriate preservation method.
\end{abstract}

\section{Farklı Koruma Yöntemlerinin Uygulandığı Siyah ve Beyaz Mersin Meyvelerindeki Bazı Biyokimyasal Parametreler}

\section{Makale Bilgileri}

Geliș: 25.02 .2021

Kabul: 18.06 .2021

Online Yayınlanma: 15.09.2021

DOI: 10.29133 /yyutbd. 886684

\author{
Anahtar Kelimeler \\ Amino asitler, \\ Antioksidan kapasite, \\ Hambeles \\ Fenolik madde, \\ Koruma, \\ Vitaminler.
}

Öz: Bu çalışmada, siyah ve beyaz Myrtus communis L. (mersin) meyvelerindeki vitaminler, karotenler, fonksiyonel peptidler, oksidatif stres biyomarkerları, toplam fenolik ve flavonoid madde, antioksidan kapasite ile amino asit içeriği araştırılmıştır. Siyah mersin meyvesi genellikle beyaz'a göre daha yüksek miktarda vitamin, fenolik madde, antioksidan ve amino asit içeriğine sahiptir. Güneşte ve mikrodalgada kurutulan mersin meyvelerinin incelenen biyokimyasal parametreleri dondurulmuş meyvelere göre daha düşük bulunmuştur $(\mathrm{P}<0.05)$. Kurutma işlemi sonucunda meyvelerin GSSG ve MDA miktarlarında önemli artış gözlenmiştir $(\mathrm{P}<0.05)$. Siyah ve beyaz mersin meyvelerindeki toplam amino asit içerikleri sırasıyla 31.37 ve $21.89 \mathrm{mg} \mathrm{g}^{-1} \mathrm{KM}$, olarak bulunmuştur. Elde edilen sonuçlardan, siyah mersin meyvesinin beyaz mersin meyvelerinden daha iyi bir besin kaynağı ve en uygun muhafaza yöntemin dondurma olduğu söylenebilir.

\section{Introduction}

The use of plants for human health is a well-established tradition for centuries. Therefore, medicinal plants are at the center of interest around the world. M. communis L. commonly known as 
"myrtle", is an endemic plant specific to the Mediterranean region. Two different type of myrtle fruits (black and white) are grown, in the Mediterranean region. Up to now black myrtle fruits has no commercial values, but in recent years it drew attention because of health benefit due to the higher antioxidant properties. Myrtle fruits are also used for curing constipation, hemorrhoids and chest diseases (Fadda and Mulas, 2010). A study conducted by Mothana et al. (2011) reported that myrtle fruits have antioxidant, antimicrobial, anticancer activities. All living organism needs vitamins as well as other nutrition's. Small quantities of vitamins are essential for organism for the proper functioning of its metabolism (Asensi-Fabad and Munne'-Bosch, 2010). Amino acids are the building blocks of proteins, and main part of food sources of living things. Amino acids are involved in neurotransmitter and biosynthesis processes in biological systems. For adequate production of protein in the body, it is necessary to take essential amino acids by diet (Davidson, 2019). Myrtle is a seasonal fruit, to be able to consume it all year around, different preservation methods are applied to the Myrtle fruits (Fadda and Mulas, 2010). Preservation techniques have a profound effect on the nutritional value and medicinal benefits of fruits. Although naturally drying in the sun is widely used, fruits can also be dried in ovens, drying tunnels, and under a vacuum as well. Microwave drying is a relatively new technique to be investigated for foodstuffs. The drying temperature, drying time, and light intensities are important factors in the nutritional content of fruits during drying processes (Maisnam et al., 2016). The aim of this study is; to compare the vitamins, carotenoids, functional peptides, OSM, TP and TF with AC of the black and white myrtle fruits. The effects of different preservation methods on these parameters with the comparison of AA contents in the white and black myrtle fruits were performed.

\section{Material and Methods}

\subsection{Materials}

Myrtle is a medicinal and aromatic plant that does not lose its leaves in winter and can grow up to 5 meters which is in tree or shrub form, and grows naturally in the form of maquis in regions with a Mediterranean climate. Due to its drought resistance, it is suitable for cultivation by planting in commercial and home gardens in other coastal regions except the eastern Black Sea. In recent years, interest in black and red colored fruits has increased due to their high antioxidant capacity.

The myrtle fruits samples were collected in November 2019 from Gözne, Mersin. The obtained fruits samples were analysed in one week of the collection. Dried samples were stored in a desiccator. Frozen samples $\left(-20^{\circ} \mathrm{C}\right)$ were analysed in ten days after drying. 20.0 gram of each fruit samples were homogenized and used throughout the analysis. Equipment and chemicals used were given in Bakar et al. (2020). Drying of fruit samples were performed according to Çakmak et al. (2021).

\subsection{Determination of fat-soluble vitamins and lycopene}

2.0 Gram of homogenized fruit samples taken and analysed according to Ibrahim et al., (2017).

\subsection{Determination of $B$ vitamins}

Analyses were carried out by HPLC using Supelcosil LC-18-DB column (150 mm x $4.6 \mathrm{~mm}$ ID, $5 \mu \mathrm{m}$ ) according to the methods of Amidžić et al. (2005) and Ibrahim et al. (2017).

\subsection{Determination of vitamin C, ghrelin, GSH, GSSG and MDA}

Analyses were performed by HPLC according to Ibrahim et al. (2017). 


\subsection{Determination of total phenolic, flavonoid substance and antioxidant capacity}

\subsubsection{Extraction}

The myrtle fruits, were homogenized with a blender, and $15.0 \mathrm{~g}$ of homogenized sample was transferred into the paper thimble and extracted with $\mathrm{CH}_{3} \mathrm{OH}$ in Soxhlet apparatus for 4 hours. The extracts dried in rotary evaporator and dissolved in a $50 \mathrm{~mL} \mathrm{CH}_{3} \mathrm{OH}$ and the solution was stored in the freezer until analysis. The prepared extract was used to determine the total phenolic substance, total flavonoid and antioxidant capacity. Determination of total phenolic and flavonoid substance were determined spectrophotometrically as described by Dewanto et al. (2002) and the results are given in as gallic acid equivalent ( $\left.\mu \mathrm{g} \mathrm{GAE} \mathrm{g}^{-1} \mathrm{DW}\right)$ with quercetin equivalent ( $\left.\mu \mathrm{g} \mathrm{QE} \mathrm{g}^{-1} \mathrm{DW}\right)$ respectively.

Total antioxidant capacity was determined according to two different methods, DPPH and TEAC.

\subsubsection{DPPH method}

The AC was measured according to Nile et al. (2013).

\subsubsection{TEAC method}

Radical-scavenging activity the of the sample was determined according to the method described by Re et al. (1999).

\subsection{Determination of amino acids}

Sample hydrolysis: $2.0 \mathrm{~g}$ of homogenised fresh fruit samples were taken into a glass tube then $5.0 \mathrm{~mL} 6.0 \mathrm{~N} \mathrm{HCl}$ was added and vortexed thoroughly followed by heating at $110{ }^{\circ} \mathrm{C}$ for 24 hours (Kwanyuen and Burton, 2010). The samples were then cooled to room temperature, filtered, then total volume was completed to $10 \mathrm{ml}$ with water.

Derivatization: Standard amino acid solutions were prepared in $0.10 \mathrm{~N} \mathrm{HCl}$ at different concentrations $\left(1.0-5.0 \mu \mathrm{g} \mathrm{mL}^{-1}\right)$ and $50 \mu \mathrm{L}$ standard amino acid solutions or hydrolysed fruit samples transferred into a $5.0 \mathrm{~mL}$ glass tubes and dried under vacuum at $65^{\circ} \mathrm{C}$. Then $50 \mu \mathrm{L}$ of reagent 1 [(2: 2 : 1 mixture of ethanol: water: Triethylamine (TEA) $(\mathrm{v} / \mathrm{v})]$ were added, vortexed and dried under vacuum at $65{ }^{\circ} \mathrm{C}$ again. Then $50 \mu \mathrm{L}$ of reagent 2 [7:1:1:1 mixture of ethanol: water: TEA: phenyl isothiocyanate (PITC) $(\mathrm{v} / \mathrm{v})]$ introduced to dried sample and vortexed then left at room temperature for 30 minutes for the complex formation in a dark place. At the end of this period, the samples were dried again under vacuum at $35^{\circ} \mathrm{C}$ (Kwanyuen and Burton, 2010) and $1.0 \mathrm{~mL}$ eluent $\mathrm{A}$ and acetonitrile (ACN) mixture $(8: 2 \mathrm{v} / \mathrm{v})$ was added, vortexed then the samples were analysed by HPLC.

Amino acid analysis: Analysis of amino acid was performed with the modified method of Kwanyuen and Burton (2010) by HPLC using Nucleodur 100-5 C18 column ( 250 x $4.6 \mathrm{~mm}, 5 \mu \mathrm{m})$. Chromatography was carried out at a constant temperature $\left(40^{\circ} \mathrm{C}\right)$ with the mobile phase consisting of eluent $\mathrm{A}$ and eluent $\mathrm{B}$ mixture with a flow rate of $0.8 \mathrm{~mL}_{\text {minute }}{ }^{-1}$ and absorption was measured at 254 nm. Eluent $\mathrm{A}$ is $0.07 \mathrm{M} \mathrm{CH}_{3} \mathrm{COONa}$ (pH was adjusted to 6.4 with $\mathrm{CH}_{3} \mathrm{COOH}$ ) and eluent $\mathrm{B}$ is a mixture of $\mathrm{ACN}$ and water $(60: 40 \mathrm{v} / \mathrm{v})$. Gradient program for amino acid analysis was as follows; $0-12$ minutes' eluents $90 \% \mathrm{~A}$ and $10 \% \mathrm{~B} ; 12-16$ minutes, $70 \% \mathrm{~A}$ and $30 \% \mathrm{~B}, 16-16.01$ minutes, $65 \% \mathrm{~A}, 35 \% \mathrm{~B}$, $16.01-25$ minutes $50 \%$ A, $50 \%$ B, 25-26 minutes \% 100B, followed by $26-35$ minutes $90 \% \mathrm{~A}$ and 10 $\% \mathrm{~B}$.

\subsection{Statistical Analysis}

All measurements were triplicated and Variance analysis was performed by SPSS 10.0 and significance was expressed as $\mathrm{P}<0.05$. 


\section{Results and Discussion}

Different conservation methods, freezing and drying being the most common ones, are applied to seasonal fruits to protect both their appeal and nutritional value for year round consumer consumption. However, such preservation methods not only affect the physical appearance of fruits but also their nutritional characteristics as well. In this study, two different types of myrtle fruits, black and white, were studied by applying different preservation methods, frozen, sun and microwave dried. The experimental analysis results were given in Figures 1 to 6 . As it can be seen from Figure 1-2, vitamins $A$, $E$, $\beta$-carotene, vitamin $B_{2}$, vitamin $B_{3}$, vitamin $B_{6}$, vitamin $B_{9}$, vitamin $B_{12}$ and vitamin $C$ in the white myrtle fruits are less than in the black fruits $(\mathrm{P}<0.05)$. The difference between lycopene and vitamin $\mathrm{B}_{1}$ in black and white myrtle fruits is statistically insignificant $(\mathrm{P}>0.05)$. The highest amounts of vitamins, $\beta$-carotene and lycopene were found in fresh myrtle, while the lowest amounts were found in sun-dried fruit samples $(\mathrm{P}<0.05)$. Vitamin loss in sun and microwave dried fruits varies between $30.0-57.0 \%$ compared to fresh fruits. As can be seen from Figures 1 and 2, the highest vitamin loss was in sun dried samples $(\mathrm{P}<0.05)$, while the least vitamin loss occurred in frozen samples $(\mathrm{P}>0.05)$.

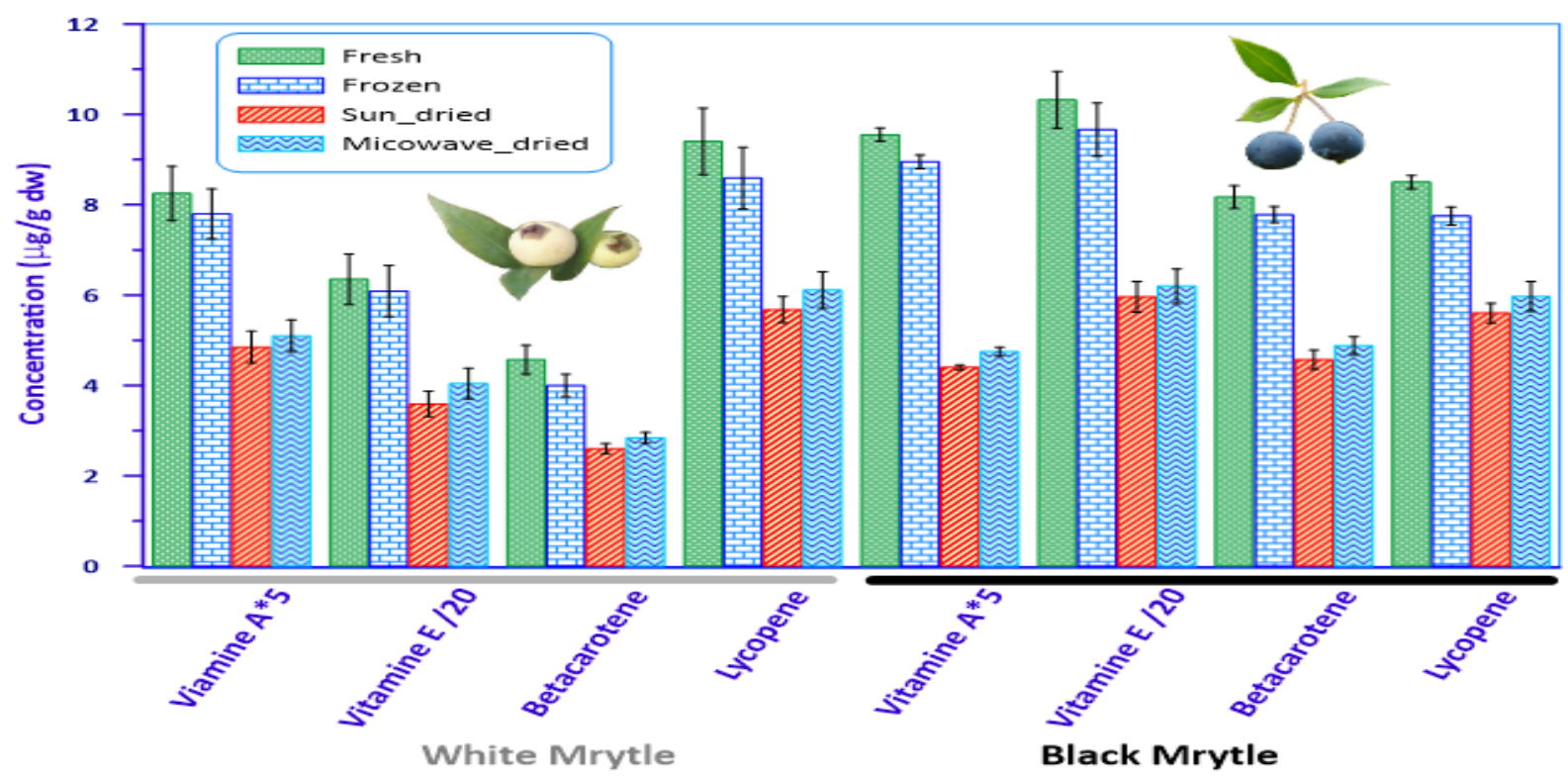

Figure 1. Contents of fat soluble vitamins and lycopene in fresh, frozen, sun and microwave dried white and black myrtle samples (for clarity and to bring into scale; vitamin A values multiplied by 5 and vitamin $\mathrm{E}$ values divided by 20 ).

Process parameters such as temperature and drying time are known to have a significant effect on the loss of vitamins. The vitamins loss in microwave dried samples was relatively less than the sundried samples, because of prolonged exposure to sun light. Obtained results consistent with the literature (Sheraz et al., 2014). Because, the shorter process time required for microwave drying, lead to lesser extend of vitamin loss, therefore microwave drying has an advantage over the sun-drying process. It was reported that the amounts of vitamins $\mathrm{B}_{1}, \mathrm{~B}_{2}, \mathrm{~B}_{3}, \mathrm{~B}_{6}$, and $\mathrm{B}_{9}$ in some fruit and vegetables (carrot, brinjal, okra, spinach, banana, and guava) were found in between $0.2-1.8,0.16-2.0,0.1-1.0,0.6-2.8$ and $0.16-1.9 \mu \mathrm{g} \mathrm{g}^{-1}$, respectively (Ismail et al., 2013). The reason the loss of vitamin, caused by the photochemical and enzymatic reactions during the sun drying process. Vitamin loss in sun-dried fruit samples is higher than microwave-dried samples. This can be explained by higher energy of sunlight to break down the vitamins and longer exposure time to dry (Sheraz et al., 2014). The loss of vitamins observed by microwaves drying can be explained by very high temperature reach in short time causing thermal degradation of fruits. 


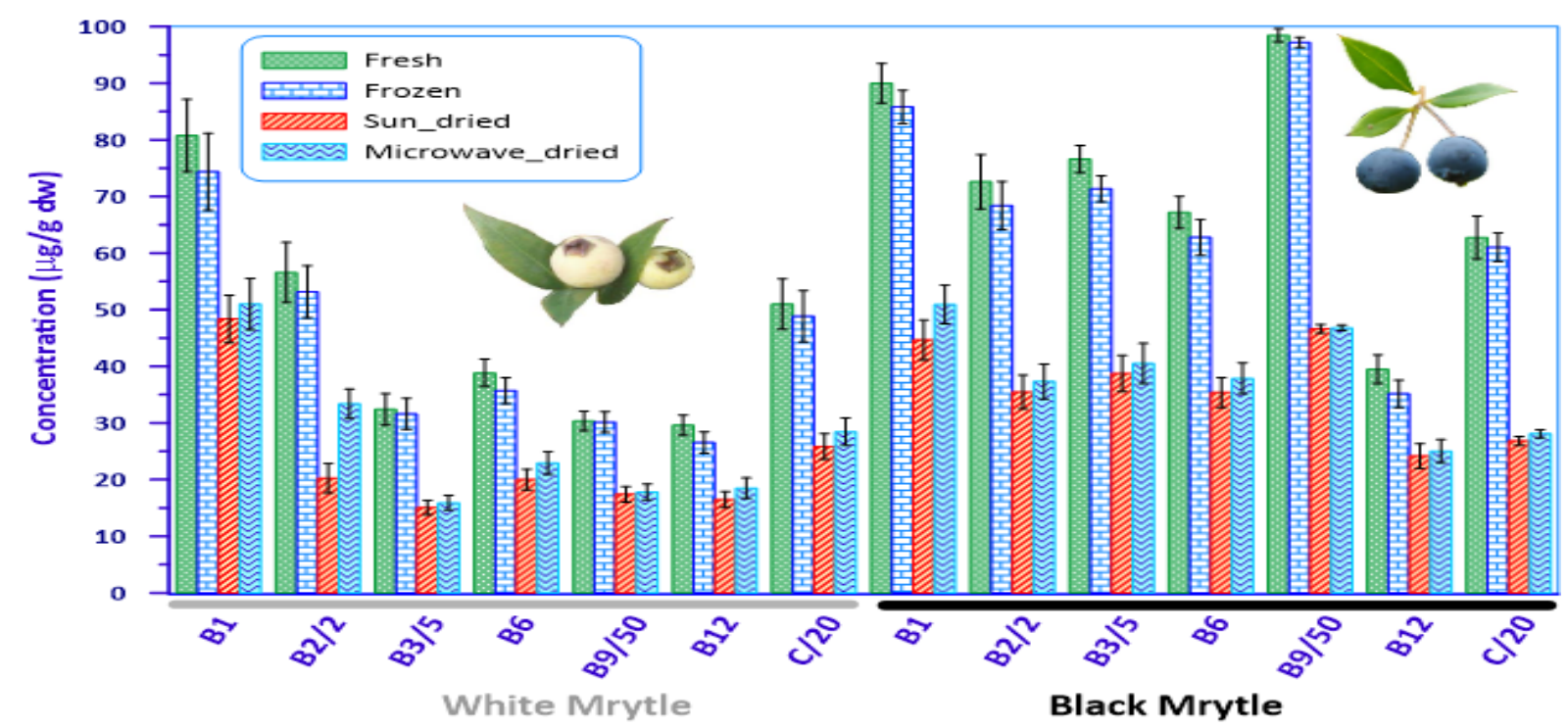

Figure 2. Contents of water soluble vitamins in fresh, frozen, sun and microwave dried white and black myrtle samples (for clarity and to bring into scale; vitamin $\mathrm{B}_{2}$ values divided by 2 , vitamin $\mathrm{B}_{3}$ values divided by 5 , vitamin $\mathrm{B}_{9}$ values divided by 50 and vitamin $\mathrm{C}$ by 20 ).

Ghrelin, which has a peptide structure, can be affected by heat treatment. Ultrasound, heat, and irradiation processing might affect protein structure and function. The amount of ghrelin in the black myrtle fruit is higher than in the white myrtle fruit. In addition, a higher amount of ghrelin was observed in the fresh samples than frozen and microwave dried samples (Figure 3). Ghrelin content in fresh, frozen, sun and microwave dried Opuntia ficus-indica fruit samples found to be 19.20, 18.80, 9.90, and $10.10 \mu \mathrm{g} \mathrm{g}^{-1} \mathrm{DW}$, respectively (Çakmak et al., 2020).

Glutathione is essential for the immune system of cells and protects cells against oxidative damage by removing reactive oxygen species. The result suggests that both black and white myrtle fruits are a rich source of GSH. The amounts of both GSH and GSSG in black myrtle fruit are $30 \%$ and $100 \%$ higher than in white myrtle fruit respectively $(\mathrm{P}<0.05)$. The GSH levels in both black and white myrtle fruits are considerably higher than the GHS values in Opuntia ficus-indica fruits (Çakmak et al., 2020). Drying myrtle fruits in the sun or microwave, cause reduced GSH levels while increasing GSSG levels significantly $(\mathrm{P}<0.05)$ (Figure 3). Preservation methods such as heat and irradiation can significantly affect the biological activity of peptides. Additionally, these processes also can cause Maillard reactions in foods. A decrease in the ratio of GSH / GSSG is the result of oxidative stress.

The value of GSH/GSSG in fresh, frozen, microwave and sun-dried black myrtle were 3.8, 3.59, 1.33 and 1.48, respectively, while it was found to be 5.94, 5.65, 2.20 and 2.47 in white myrtle samples. As a result of the drying process, the GSH/GSSG ratio in both black and white myrtle fruits decreased significantly.

Another stress biomarker is MDA which is also a cellular stress indicator and is formed as a result of lipid peroxidation caused by free radicals (Gawel et al., 2004). It was observed that MDA in black and white myrtle varies between 6.68- 7.62 and 5.83- 8.13 $\mu \mathrm{g} \mathrm{g}^{-1} \mathrm{DW}$, respectively (Figure 3). Drying processes, significantly increase the amount of MDA level in myrtle fruits $(\mathrm{P}<0.05)$. Our findings are consistent with the results obtained in apricot dried by infrared and microwave (Karatas and Kamisli, 2007). While GSH/GSSG ratio decreased, the amount of MDA increased as a result of drying processes. 


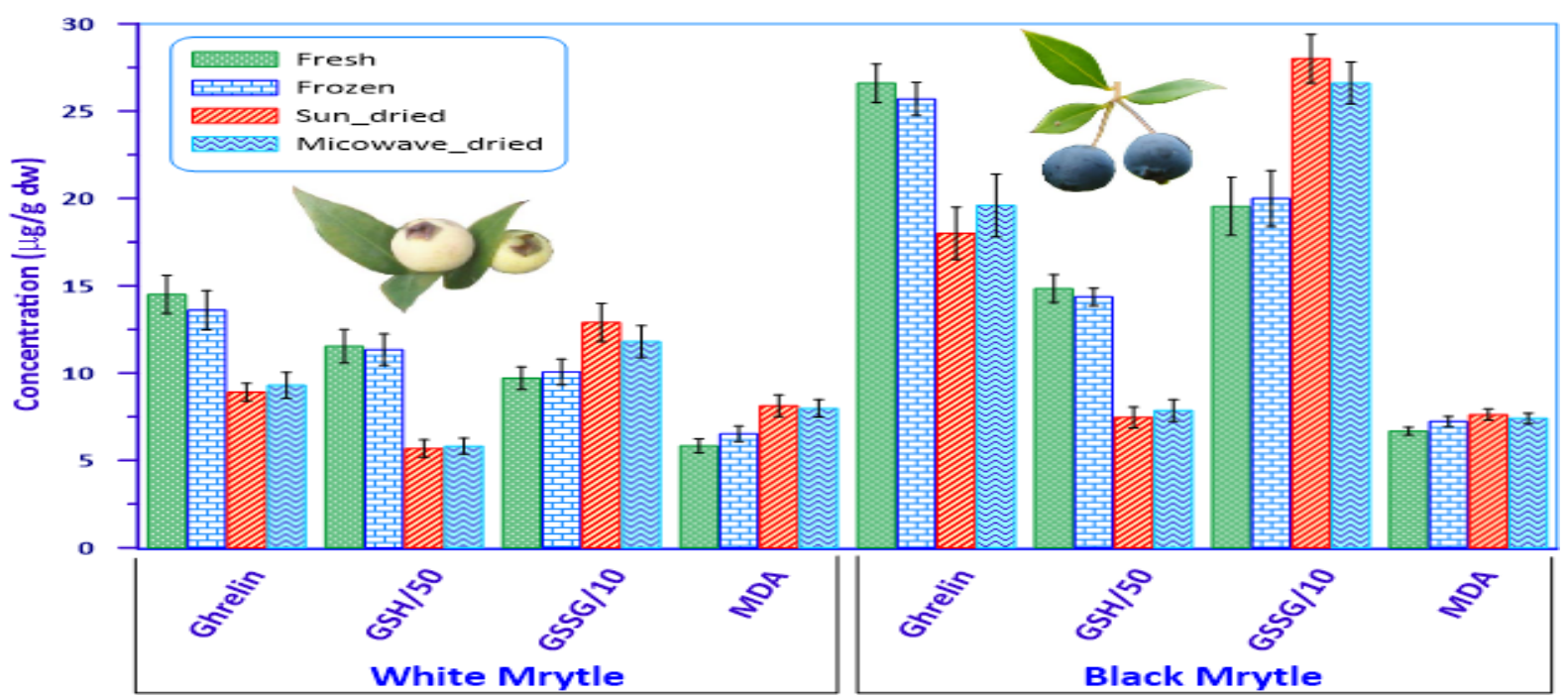

Figure 3. Contents of ghrelin, GSH, GSSG and MDA, in fresh, frozen, sun and microwave dried white and black myrtle samples (for clarity and to bring into scale; GSH value divided by 50 and GSSG value divided by 10).

Phenolic compounds found in plants function as antioxidant, antimutagenic, anticarcinogenic, and play a role in altering gene expression (Datta et al., 2019). The total of phenolic substance in the black myrtle fruit is more than that in the white fruits $(\mathrm{P}<0.05)$. The change in the total amount of phenolic substances as a result of the drying process is not statistically significant ( $\mathrm{P}>0.05)$ (Figure 4). Patil et al. (2019) found the total phenolic content of Opuntia Ficus-indica fruits as $42.454 \mathrm{mg} \mathrm{GAE} / 100 \mathrm{~g}$. Total phenolic content, DPPH, and ABTS values of green walnuts were reported as 17842.26-6907.83 mg GAE kg-1, 208.8-49.03 and 208.48-66.97 $\mathrm{mmol} \mathrm{TE} \mathrm{g}^{-1}$, respectively (Uğurlu et al. 2019).

Different studies investigated the effect of drying on phenolic compounds in fruits. While Zanoelo et al. (2006) reported the decrease in the total amount of phenolic substances on drying fruit samples, Dewanto et al. (2002) reported that the total phenolic compound unchanged. As a result of heat treatment, some phenolic compounds may decompose or new phenolic compounds may form. Therefore, depending on the drying process and type of fruits, changes in the total phenolic substance may not be the same for each fruit after drying.

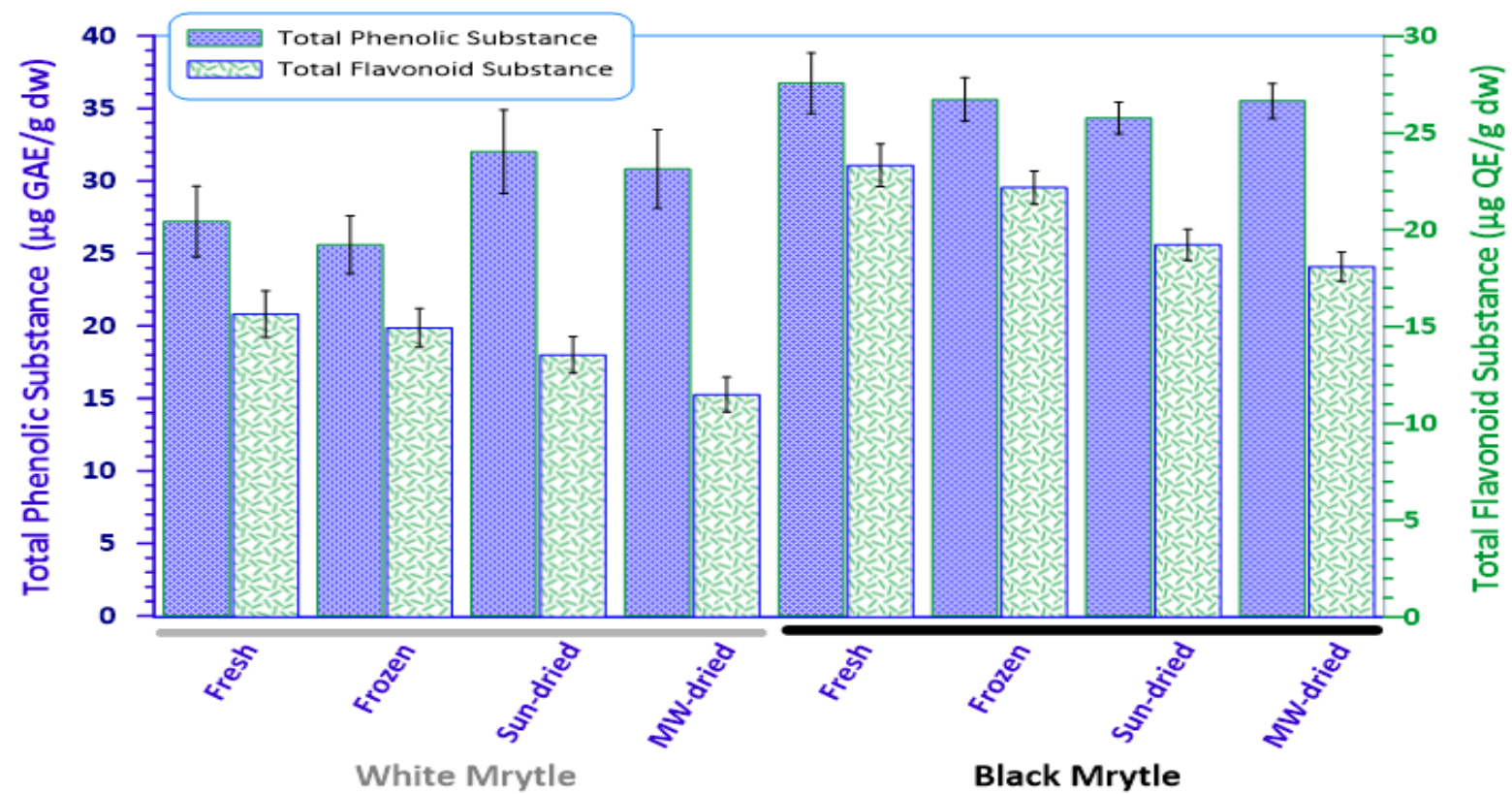

Figure 4. Contents of total phenolic substance and Flavonoid in fresh, frozen, sun and microwave dried white and black myrtle samples. 
The total flavonoid content in black myrtle fruits is quite higher $\left(23.33 \mu \mathrm{g} \mathrm{QE} \mathrm{g}{ }^{-1} \mathrm{DW}\right)$ than white myrtle fruits $\left(15.65 \mu \mathrm{g} \mathrm{QE} \mathrm{g}^{-1} \mathrm{DW}\right)(\mathrm{p}<0.05)$. (Figure 4). While the least flavonoid lost was observed in frozen fruits, the highest decrease was observed in MW dried samples. Flavonoids are the substances that cause the colouring of fruits which involve in the activity of some enzymes (Panche et al., 2016). The total amount of flavonoids in Opuntia ficus-indica fruit has been reported as 1.91 (mg QE g ${ }^{-1}$ DW) (Hahm et al., 2015). The results obtained showed that while the least loss of flavonoid was observed in frozen myrtle $(\mathrm{P}>0.05)$, the highest loss was observed in the microwave dried samples $(\mathrm{P}<0.05)$. This can be explained by the decomposition of some flavonoids at high temperatures during microwave drying process. Drying vegetables and fruits under different conditions has been reported to cause $3 \%$ to $96 \%$ decrease in the total amount of flavonoids (Kamiloglu et al., 2015).

Antioxidants are molecules that are generally produced from natural sources, contain phenolic groups and, inhibit the free radical formation or neutralize them ( $\mathrm{Su}$ et al., 2007). $\mathrm{IC}_{50}$ and trolox equivalent were calculated to determine the antioxidant capacity. As can be seen from Figure 5, $\mathrm{IC}_{50}$ values in black myrtle fruit lower than white myrtle fruit which indicates high antioxidant activity. On the other hand, the highest $\mathrm{IC}_{50}$ value of myrtle fruits were observed in the sun-drying process. Surinut et al. (2005) reported that the $\mathrm{IC}_{50}$ values of mangosteen, orange, pomelo, grape, and papaya fruits ranged from 11.18 to $32.80 \mathrm{mg} \mathrm{mL}^{-1}$.

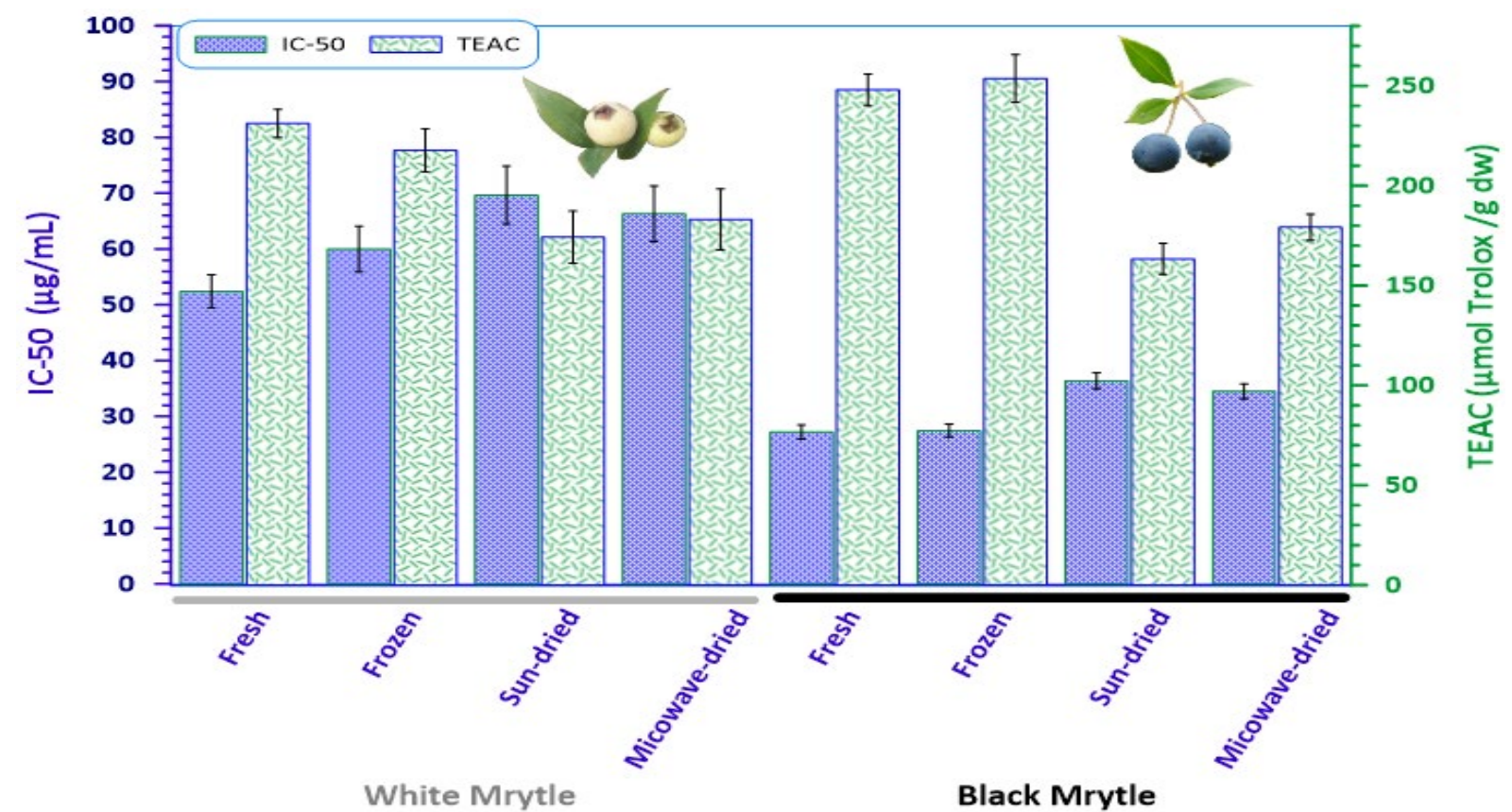

Figure 5. TEAC and $\mathrm{IC}_{50}$ values of fresh, frozen, sun and microwave dried black and white myrtle fruits.

TEAC values of black myrtle fruits have significantly higher than the white fruits $(\mathrm{P}<0.05)$. TEAC value decreased significantly because of drying process $(\mathrm{P}<0.05)$ (Figure 5). The decrease in total antioxidant capacity might be the result of the breakdown of vitamins, phenolic, and flavonoid substances. Su et al. (2007) reported that the antioxidant activity of rosehip fruit was $190 \mu \mathrm{mol}$ TEAC $\mathrm{g}^{-1}$.

One of the main source of amino acid is known as vegetables, fruits and plants. The determination of amino acids in vegetation has become an important subject in recent years. Essential amino acids used in protein synthesis and metabolism, must be taken with the diet. Experimental results of amino acids in black and white myrtle fruits are given in Figure 6. The essential amino acid content in black myrtle fruit ranges from 0.75 to $2.30 \mathrm{mg} \mathrm{g}^{-1} \mathrm{DW}$, while the total essential amino acid content was found to be $13.47 \mathrm{mg} \mathrm{g}^{-1} \mathrm{DW}$. The total amount of amino acids in the black myrtle fruit was found to be $31.37 \mathrm{mg} \mathrm{g}^{-1} \mathrm{DW}$, while it was as $21.89 \mathrm{mg} \mathrm{g}^{-1} \mathrm{DW}$ in the white fruits $(\mathrm{P}<0.05)$ (Figure 6). 


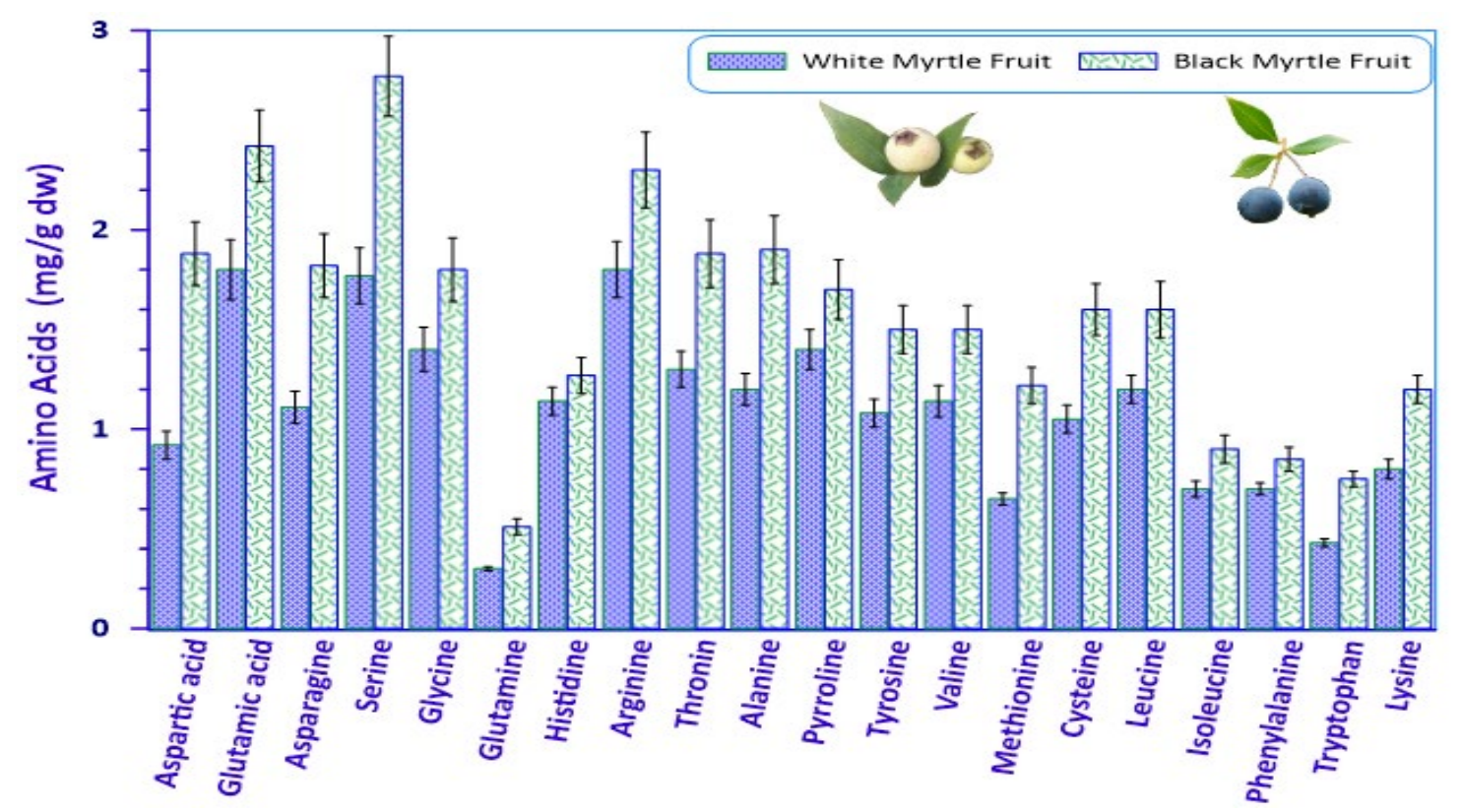

Figure 6. Contents of amino acids in black and white myrtle samples.

The amount of essential amino acid content in white myrtle fruit ranges from 0.43 to $1.84 \mathrm{mg} \mathrm{g}^{-}$ ${ }^{1}$ DW, while the total essential amino acid content to be $9.86 \mathrm{mg} \mathrm{g}^{-1}$ DW. Zhou et al. (2019) in their study using Nitraria tangutorum Bobr pulp and peel, reported the total essential amino acids ranged from 44.39-53.51 mg g ${ }^{-1} \mathrm{DW}$, and the total non-essential amino acids ranged from $65.65-71.41 \mathrm{mg} \mathrm{g}^{-1}$ DW. According to the Food and Agriculture Organization and the World Health Organization, the total essential amino acid/total amino acid ratio in a good protein source should be over $40 \%$, while the total essential amino acid/total non-essential amino acid ratio should be over $60 \%$ (Zhou et al., 2019). Total essential amino acid/total amino acid and total essential amino acid/total non-essential amino acid ratio for black and white myrtle fruit were found to be 43.0, 75.0, 45.0 and 82.0 percent, respectively.

\section{Conclusions}

Myrtle fruits are a good source of nutrients in vitamins, carotenes, lycopene, glutathione, ghrelin, antioxidants capacity and amino acids. And black fruits are a good source of nutrients than white fruits. Obtained results indicate that there is no significant difference between in fresh and frozen myrtle fruits in terms of the biochemical parameters examined. Content of vitamins, total phenolic and flavonoid compounds, and antioxidant capacity in fresh and frozen myrtle fruit samples have higher than the sun and microwave-dried fruit samples. Since vitamins and antioxidants are very sensitive to light, heat, and air, drying conditions effect on these parameters. It was found that while the GSH/GSSG ratio decreased, while MDA level increased in dried myrtle fruits. It can also be said that the drying process causes stress in the fruits resulting in lipid peroxidation. Experimental findings, suggests that the most suitable method for preservation for myrtle fruits is freezing.

\section{References}

Amidžić, R., Brborić, J., Čudina, O., \& Vladimirov, S. (2005). Rp-HPLC determination of vitamins, folic acid and B12 in multivitamin tablets, J Serbian Chem Society C., 70, 1229-1235.

Asensi-Fabado, M.A., \& Munne'-Bosch, S. (2010). Vitamins in plants: occurrence, biosynthesis and antioxidant function. Trends Plant Sci. 15(10), 582-592.

Bakar, B., Çakmak, M., Ibrahim, M. S., Özer, D., Saydam, S., \& Karatas, F. (2020). Investigation of Amounts of Vitamins, Lycopene, and Elements in the Fruits of Opuntia ficus-indica Subjected to Different Pretreatments. Biol Trace Elem Res., 198(1), 315-323. 
Çakmak, M., Bakar, B., Ibrahim, M. S., Özer, D., Karatas, F., \& Saydam, S. (2020). Effect of Freezing and Drying Methods on Some Biochemical Properties of Prickly Fig (Opuntia ficus-indica) Fruit. YYU J Agric Sci., 30(3), 535-543.

Çakmak, M., Bakar, B., Özer, D., Geckil, H., Karatas, F., \& Saydam, S. (2021). Investigation of some biochemical parameters of wild and cultured Myrtus communis L. fruits subjected to different conservation methods. J Food Meas Charact., 15(1), 983-993

Datta, S., Sinha, B. K., Bhattacharjee, S., \& Seal, T. (2019). Nutritional composition, mineral content, antioxidant activity and quantitative estimation of water soluble vitamins and phenolics by RP-HPLC in some lesser used wild edible plants. Heliyon, 5(3), e01431.

Davidson, J. A. (2019). Amino Acids in Life: A Prebiotic Division of Labor. J Mol Evol. https://doi.org/10.1007/s00239-018-9879-z.

Dewanto, V., Wu, X., Adom, K. K., \& Liu, R. H. (2002). Thermal processing enhances the nutritional value of tomatoes by increasing total antioxidant activity. J Agric Food Chem. 50, 3010-3014.

Fadda, A., \& Mulas, M. (2010). Chemical changes during myrtle (Myrtus communis L.) fruit development and ripening. Sci Hortic., 125, 477- 485.

Hahm, S. W., Park, J., Oh, S. Y., Lee, C. W., Park, K. Y., Kim, H., \& Son, Y. S. (2015). Anticancer Properties of Extracts from Opuntia humifusa Against Human Cervical Carcinoma Cells. $J$ Med Food., 18(1), 31-44.

Ibrahim, M. S., Ibrahim, Y. I., Mukhtar, Z. G., \& Karatas, F. (2017). Amount of Vitamin A, Vitamin E, Vitamin C, Malondialdehyde, Glutathione, Ghrelin, Beta-Carotene, Lycopene in Fruits of Hawthorn, Midland (Crataegus laevigata). J Hum Nutr Food Sci., 5(3), 1112-1117.

Ismail, F., Talpur, F.N., \& Memon, A.N. (2013). Determination of Water Soluble Vitamin in Fruits and Vegetables Marketed in Sindh Pakistan. Pakistan J Nutr. 12(2), 197-199.

Kamiloglu, S., Toydemir, G., Boyacioglu, D., Beekwilder, J., Hall, R.D., \& Capanoglu, E. (2015). A review on the effect of drying on antioxidant potential of fruits and vegetables. Crit Rev Food Sci Nutr. 56(1), 110-129.

Karatas, F., \& Kamisli, F. (2007). Variations of vitamins (A, C and E) and MDA in apricots dried in IR and microwave. J Food Eng. 78, 662-668.

Kwanyuen, P., \& Burton, J.W. (2010). A Modified Amino Acid Analysis Using PITC Derivatization for Soybeans with Accurate Determination of Cysteine and Half-Cystine. J Am Oil Chem Soc. 87(2), 127-132.

Maisnam, D.; Rasane, P.; Dey, A.; Kaur, S. \& Sarma, C. (2016). Recent advances in conventional drying of foods. J Food Technol Pres., 1(1), 25-34.

Mothana, R.A.A., Kriegisch, S., Harms, M., Wende, K., \& Lindequist, U. (2011). Assessment of selected Yemeni medicinal plants for them in vitro antimicrobial, anticancer, and antioxidant activities. Pharm Biol. 49 (2), 200-210.

Nile, S.H., Kim, S.H., Ko, E.Y., \& Park, S.W. (2013). Polyphenolic Contents and Antioxidant Properties of Different Grape ( $V$. vinifera, V. labrusca, and V. hybrid) Cultivars. Biomed Research International, Article ID 718065: 1-5.

Panche, A.N., Diwan, A.D., \& Chandra, S.R. (2016). Flavonoids: an overview. J Nutr Sci. 5 (47), 1-15.

Patil, K.V., Dagadkhair, A.C., Bhoite, A.A., \& Andhale, R.R. (2019). Physico-functional characteristics of Opuntia Ficus-indica. Int J Food Sci Nutr. 4(6), 124-127.

Re, R., Pellegrini, N., Proteggente, A., Pannala, A., Yang, M., \& Rice-Evans, C. (1999). Antioxidant activity applying an improved ABTS radical cation decolorization assay. Free Radic Biol Med. 26, 1231-1237.

Sheraz, M.A., Kazi, S.H., Ahmed, S., Anwar, Z., \& Ahmad, I. (2014). Photo, thermal and chemical degradation of riboflavin. Beilstein J Org Chem. 10, 1999-2012.

Su, L., Yin, J., Charles, D., Zhou, K., Moore, J., \& Yu, L. (2007). Total phenolic contents, chelating capacities, and radical-scavenging properties of black peppercorn, nutmeg, rosehip, cinnamon and oregano leaf. Food Chem. 100, 990-997.

Su, L., Yin, J., Charles, D., Zhou, K., Moore, J., \& Yu, L. (2007). Total phenolic contents, chelating capacities, and radical-scavenging properties of black peppercorn, nutmeg, rosehip, cinnamon and oregano leaf. Food Chem. 100, 990-997.

Surinut, P., Kaewsutthi, S., \& Surakarnkul, R. (2005). Radical Scavenging Activity in Fruit Extracts. Acta Horticulturae, 679, 201-203. 
Uğurlu, S., Okumuş, E., \& Bakkalbaşı, E. (2019). Van Gölü Kıyısında Farklı Dönemlerde Hasat Edilen Yeşil Cevizlerin Fenolik Madde İçerikleri ve Antioksidan Aktiviteleri. YYÜ Tar Bil Derg., 29 (3), 440-449.

Zanoelo, E.F., Cardozo-Filho, L., \& Cardozo-Junior, E.L. (2006). Superheated steam drying of mate leaves and effect of drying conditions on the phenol content. J Food Process Eng. 29(3): 253268.

Zhou, W., Wang, Y., Yang, F., Dong, Q., Wang, H., \& Hu, N. (2019). Rapid Determination of Amino Acids of Nitraria tangutorum Bobr. from the Qinghai-Tibet Plateau Using HPLC-FLDMS/MS and a Highly Selective and Sensitive Pre-Column Derivatization Method. Molecules 24, 1665; doi:10.3390/molecules24091665 